\title{
NKT cell-dependent leukemia eradication following stem cell mobilization with potent G-CSF analogs
}

Edward S. Morris, ${ }^{1,2}$ Kelli P.A. MacDonald, ${ }^{1}$ Vanessa Rowe, ${ }^{1}$ Tatjana Banovic, ${ }^{1}$ Rachel D. Kuns, Alistair L.J. Don, ${ }^{1}$ Helen M. Bofinger, ${ }^{1}$ Angela C. Burman, ${ }^{1}$ Stuart D. Olver, ${ }^{1}$ Norbert Kienzle, ${ }^{1}$ Steven A. Porcelli, ${ }^{3}$ Daniel G. Pellicci, ${ }^{4}$ Dale I. Godfrey, ${ }^{4}$ Mark J. Smyth, ${ }^{5}$ and Geoffrey R. Hill1,2

\begin{abstract}
${ }^{1}$ Queensland Institute of Medical Research, Brisbane, Queensland, Australia. ${ }^{2}$ Department of Stem Cell Transplantation, Royal Brisbane Hospital, Brisbane, Queensland, Australia. ${ }^{3}$ Department of Microbiology and Immunology, Albert Einstein College of Medicine, New York, New York, USA. ${ }^{4}$ Department of Microbiology and Immunology, University of Melbourne, Parkville, Victoria, Australia. ${ }^{5}$ Cancer Immunology Program, Trescowthick Laboratories, Peter MacCallum Cancer Centre, St. Andrews Place, Victoria, Australia.
\end{abstract}

\begin{abstract}
NKT cells have pivotal roles in immune regulation and tumor immunosurveillance. We report that the GCSF and FMS-like tyrosine kinase 3 ligand (Flt-3L) chimeric cytokine, progenipoietin-1, markedly expands the splenic and hepatic NKT cell population and enhances functional responses to $\alpha$-galactosylceramide. In a murine model of allogeneic stem cell transplantation, donor NKT cells promoted host DC activation and enhanced perforin-restricted $\mathrm{CD8}^{+} \mathrm{T}$ cell cytotoxicity against host-type antigens. Following leukemic challenge, donor treatment with progenipoietin-1 significantly improved overall survival when compared with G-CSF or control, attributable to reduced graft-versus-host disease mortality and paradoxical augmentation of graft-versus-leukemia (GVL) effects. Enhanced cellular cytotoxicity was dependent on donor NKT cells, and leukemia clearance was profoundly impaired in recipients of NKT cell-deficient grafts. Enhanced cytotoxicity and GVL effects were not associated with Flt-3L signaling or effects on DCs but were reproduced by prolonged G-CSF receptor engagement with pegylated G-CSF. Thus, modified G-CSF signaling during stem cell mobilization augments NKT cell-dependent $\mathrm{CD8}^{+}$cytotoxicity, effectively separating graft-versus-host disease and GVL and greatly expanding the potential applicability of allogeneic stem cell transplantation for the therapy of malignant disease.
\end{abstract}

\section{Introduction}

Type 1 NKT cells are a unique subset of CD1d restricted $\alpha \beta-T$ cells that express highly conserved semi-invariant TCR $(1,2)$. Recognition of glycolipid antigens in association with the nonpolymorphic CD1d molecule (3) characteristically leads to rapid production of a range of immunomodulatory cytokines including IFN- $\gamma$ and IL-4 (4). NKT cells play important roles in the regulation of transplant tolerance (5-8) and are key components in both innate $(9,10)$ and adaptive $(11-13)$ tumor responses.

Allogeneic hemopoietic stem cell transplantation (SCT) is the definitive therapy for an increasing variety of hematological and nonhematological malignancies. Following allogeneic SCT, however, beneficial immunological graft-versus-leukemia (GVL) effects are frequently effaced by the development of destructive graft-versus-host disease (GVHD). Administration of G-CSF leads to mobilization of hemopoietic progenitors from the bone marrow to the peripheral blood (reviewed in ref. 14), which may be collected and utilized as the stem cell source for allogeneic SCT. Donor mobilization with cytokines reduces T cell-mediated GVHD (15-23) although the definitive mechanism remains to be determined.

\footnotetext{
Nonstandard abbreviations used: Flt-3L, FMS-like tyrosine kinase 3 ligand; $\alpha$-GalCer, $\alpha$-galactosylceramide; GM, granulocyte-monocyte (regulatory APC population); GVHD, graft-versus-host disease; GVL, graft versus leukemia; Peg-G-CSF, pegylated G-CSF; ProGP-1, progenipoietin-1; SCT, stem cell transplantation; TRAIL, TNF-related apoptosis-inducing ligand. Conflict of interest: The authors have declared that no conflict of interest exists. Citation for this article: J. Clin. Invest. 115:3093-3103 (2005). doi:10.1172/JCI25249.
}

Despite being closely related, GVL effects may be observed in the absence of GVHD (24). Meaningful separation in clinical practice, however, remains the focus of intense study $(16-22,25,26)$.

Progenipoietin-1 (ProGP-1) is a potent chimeric cytokine that stimulates both G-CSF and FMS-like tyrosine kinase 3 ligand (Flt-3L) receptors (27-29) and significantly reduces GVHD in a preclinical model of hemopoietic SCT (30). Concurrent preservation of the GVL effect is essential for the effective management of malignant disease, and we report that donor mobilization with ProGP-1 in fact enhances NKT cell-dependent leukemia eradication and effectively separates GVHD and GVL effects.

\section{Results}

ProGP-1 expands activated type 1 NKT cells and enhances in vitro responses to $\alpha$-galactosylceramide. Since NKT cells play important roles in the regulation of transplant tolerance $(5-8,31)$ and are expanded in transgenic mice overexpressing human G-CSF (32), we examined the effects of cytokine mobilization with G-CSF or ProGP-1 on NKT cell number and function. Donor mobilization with ProGP-1 markedly expands DCs and granulocytes within the spleen (30) and liver (data not shown). As shown in Figure 1A, although the relative proportions of type 1 NKT cells within the liver and spleen of ProGP-1-treated donors are reduced, the total numbers of both $\mathrm{CD}^{+}$and double-negative (CD4- $\left.{ }^{-} 8^{-}\right)$NKT cells are increased, as is the expression of the activation marker CD69 on these cells. In contrast, mobilization with G-CSF had minimal effects on NKT cell numbers or activation (Figure 1A). In vitro stimulation of ProGP-1-mobilized whole spleen with the 

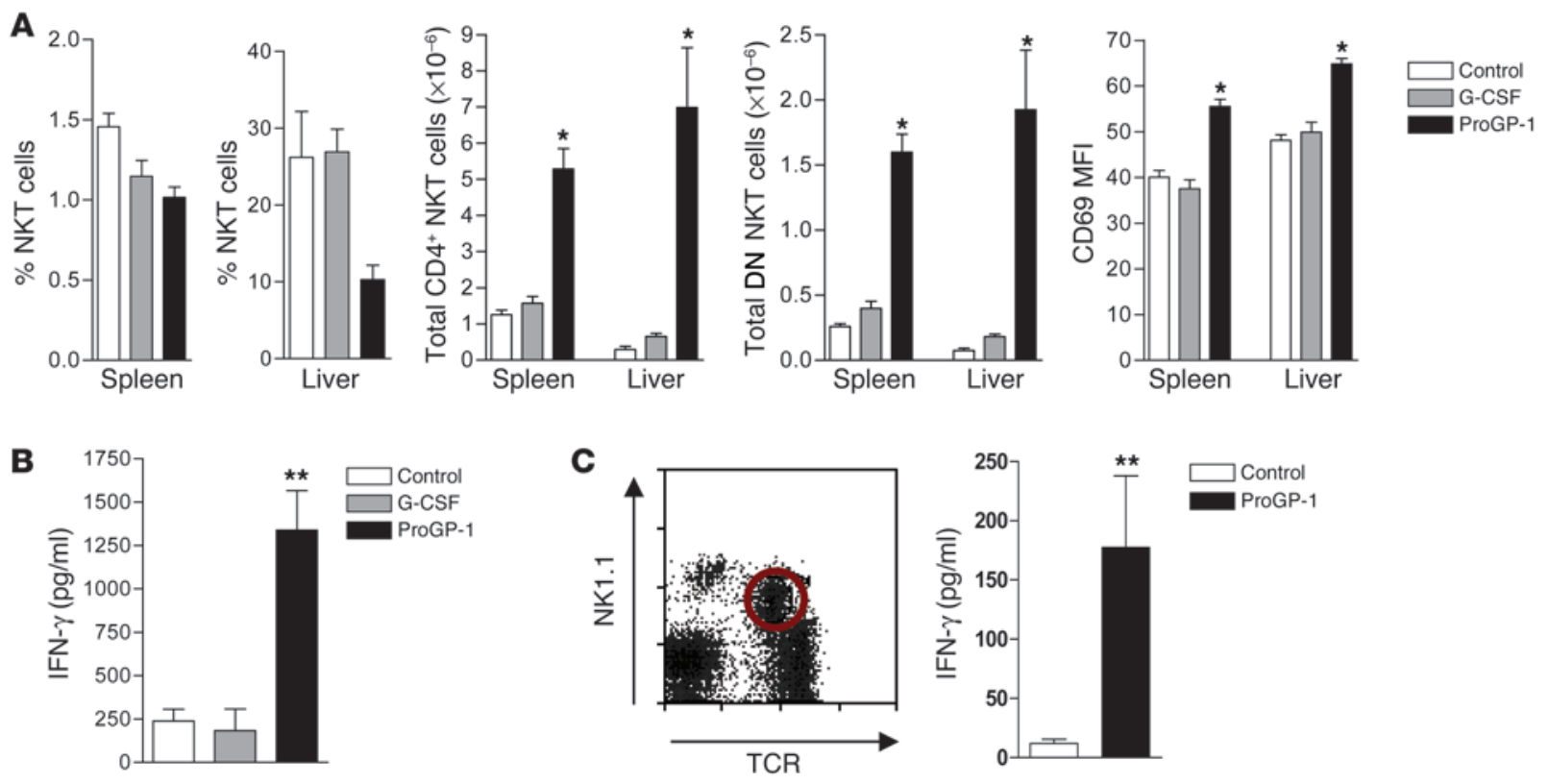

Figure 1

ProGP-1 expands type $1 \mathrm{NKT}$ cells and enhances in vitro responses to $\alpha$-GalCer. (A) C57BL/6 mice received control diluent, G-CSF, or ProGP-1. The relative proportion, absolute number, and mean fluorescence intensity (MFI) of CD69 staining of type 1 NKT cells (defined as $\alpha$-GalCer-loaded CD1d tetramer $+\alpha \beta \mathrm{TCR}^{+}$) were determined by FACS analysis (control, $n=3$; G-CSF, $n=6$; ProGP-1, $n=6$ ). * $P \leq 0.05$ vs. other groups. Combined data from 2 experiments shown. DN, double negative. (B) Whole spleen $\left(5 \times 10^{6}\right.$ cells) was cultured with $\alpha$-GalCer (C20:2) and supernatant IFN- $\gamma$ determined by ELISA after 24 hours. ${ }^{* \star} P<0.05$ vs. other groups. Combined data from 2 experiments shown. (C) NKT cells were sorted from control or ProGP-1-mobilized splenocytes as the CD11b-, 7-aminoactinomycin D negative, TCR ${ }^{+}, \mathrm{NK}_{1.1}{ }^{+}$population (circled). Sorted NKT cells $\left(2.5 \times 10^{4}\right.$ cells) were cultured with purified DCs $\left(2.5 \times 10^{4}\right.$ cells $)$ and $\alpha$-GalCer (C20:2); supernatant IFN- $\gamma$ was determined by ELISA after 24 hours. ${ }^{*} P<0.05$ vs. control. Combined data from 2 experiments shown.

$\alpha$-galactosylceramide ( $\alpha$-GalCer) analog C20:2 resulted in increased production of IFN- $\gamma$ (Figure 1B). Since IFN- $\gamma$ production by NKT cells in response to TCR ligation will also reflect the efficiency of glycolipid presentation by APCs within spleen, which is likely to be enhanced in ProGP-1 splenocytes, purified NKT cells were also stimulated with $\alpha$-GalCer (C20:2) in the presence of purified DCs. As shown in Figure 1C, NKT cells from ProGP-1-mobilized donors produced significantly more IFN- $\gamma$ when compared with those from control donors. Thus donor mobilization with ProGP-1 expands and activates type 1 NKT cells that have enhanced functional responses to TCR stimulation.

ProGP-1 increases $C D 8^{+} T$ cell cytotoxicity following allogeneic SCT with "belp" provided by $C D 4^{+} T$ cells and type 1 NKT cells. Since NKT cells have roles in both immunoregulation and tumor surveillance (1, 33 ), we next determined relative levels of in vivo cellular cytotoxicity (using the in vivo cytotoxicity assay described in Methods) following G-CSF or ProGP-1 mobilization. Following syngeneic SCT (B6D2F1 to B6D2F1), the in vivo cytotoxicity index was approximately 1 in all recipients irrespective of donor mobilization with G-CSF or ProGP-1 (Figure 2A). Thus, in the absence of alloreactivity, splenocytes infused at day 12 distribute equally regardless of donor mobilization. Following allogeneic (C57BL/6 to B6D2F1) SCT, however, in vivo cytotoxicity was significantly greater in recipients of ProGP-1-mobilized grafts (Figure 2A), and this was confirmed by ex vivo ${ }^{51} \mathrm{Cr}$-release cytotoxicity assays (Figure $2 \mathrm{~B}$ ).

To examine the relative contributions of different $T$ cell subsets to cytotoxicity, lethally irradiated mice received grafts from ProGP-1mobilized WT or type 1 NKT cell-deficient (J $\left.\alpha 18^{-/-}\right)$donors. Grafts consisted of whole spleen or WT splenocytes depleted of $\mathrm{CD}^{+} \mathrm{T}$ cells, $\mathrm{CD}^{+} \mathrm{T}$ cells, or both. $\mathrm{CD}^{+} \mathrm{T}$ cells $(\mathrm{CD} 8 \alpha \beta)$ were specifically depleted with anti-CD8 $\beta$, allowing preservation of $\mathrm{CD}^{+} \mathrm{DCs}$ $(C D 8 \alpha \alpha)$ (Supplemental Figure 1A; supplemental material available online with this article; doi:10.1172/JCI25249DS1). As shown in Figure 2C, in vivo cytotoxicity to host antigens was almost completely abolished following depletion of $\mathrm{CD}^{+} \mathrm{T}$ cells. Cytotoxicity in recipients of grafts depleted of only $\mathrm{CD} 4^{+} \mathrm{T}$ cells or from $\mathrm{J} \alpha 18^{-/-}$ donors (containing equivalent proportions and numbers of $\mathrm{T}$ cell subsets; ref. 34) was reduced although not abolished. $\mathrm{CD}^{+} \mathrm{T}$ cell reconstitution, however, was not impaired following the transplantation of grafts lacking CD4 ${ }^{+} \mathrm{T}$ cells or NKT cells (Supplemental Figure 1B). Since the type $1 \mathrm{NKT}$ cell compartment in mice consists of $\mathrm{CD}^{+}$and double-negative (CD4-CD8 $\left.{ }^{-}\right)$NKT cells (1), we also determined in vivo cytotoxicity in recipients of ProGP-1-mobilized grafts consisting of CD4-depleted splenocytes plus purified CD4 ${ }^{+}$ T cells from either WT or J $\alpha 18^{-/-}$donors. As shown in Figure $2 \mathrm{C}$, cytotoxicity in recipients of CD4-depleted grafts plus Ja18-/- CD4+ $\mathrm{T}$ cells (containing conventional $\mathrm{CD} 4^{+} \mathrm{T}$ cells but not $\mathrm{CD} 4^{+} \mathrm{NKT}$ cells) returned to levels seen in recipients of unmanipulated WT grafts. Thus, reduced cytotoxicity following CD4 depletion is due to loss of conventional $\mathrm{CD}^{+} \mathrm{T}$ cells rather than $\mathrm{CD} 4^{+} \mathrm{NKT}$ cells. In addition, this suggests that the presence of double-negative NKT cells allows maximal enhancement of cytotoxicity. In ${ }^{51} \mathrm{Cr}$-release assays, donor $\mathrm{CD}^{+} \mathrm{T}$ cells from recipients of whole spleen exerted significantly increased cytotoxicity against host antigens relative to recipients of CD4-depleted or NKT cell-deficient splenocytes (Figure 2D). Purified donor $\mathrm{CD}^{+} \mathrm{T}$ cells, however, failed to exert direct 
A

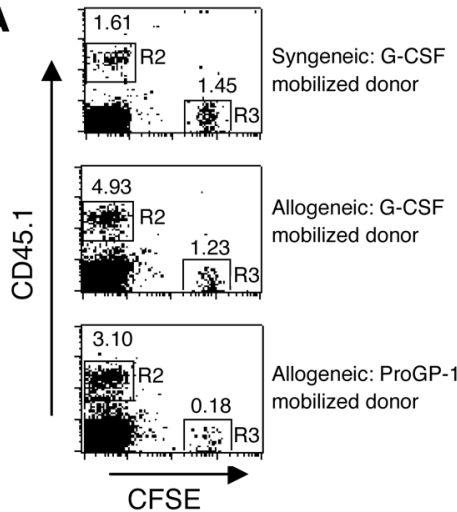

C

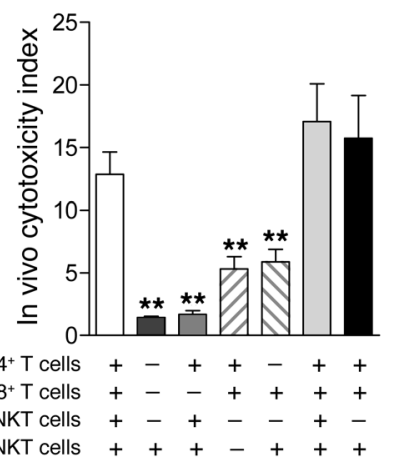

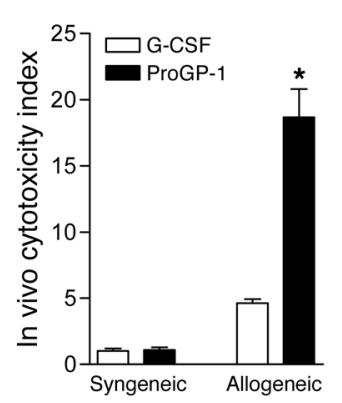

B

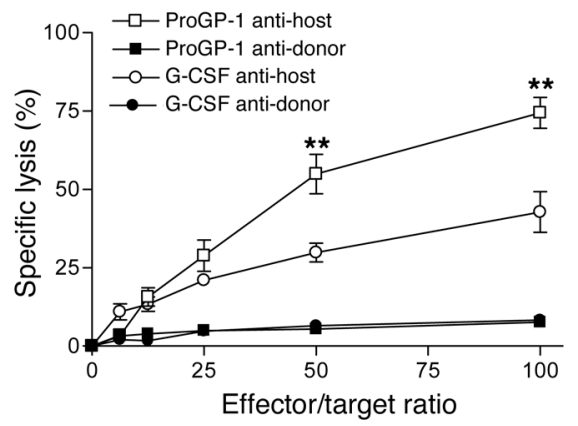

$\square$ WT nondepleted

WT CD4 ${ }^{+}$and $\mathrm{CD} 8^{+}$depleted

$\square$ WT CD8 depleted

J $118^{-1-}$

$\square$ WT CD4+ depleted

$\square$ WT CD4+ depleted + WT CD4

WT CD4 $4^{+}$depleted + J $\alpha 18^{-/-} \mathrm{CD}^{+}$

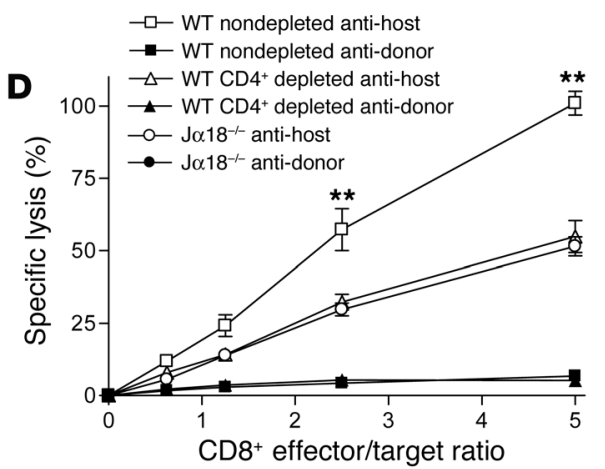

CD8 ${ }^{+}$effector/target ratio

Figure 2

E

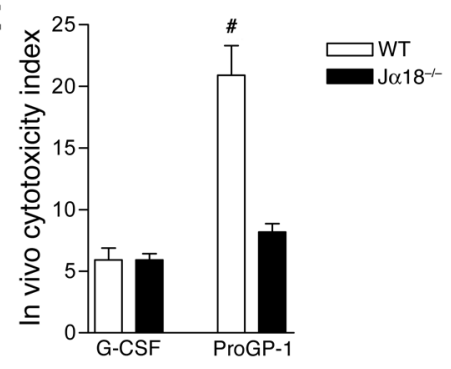

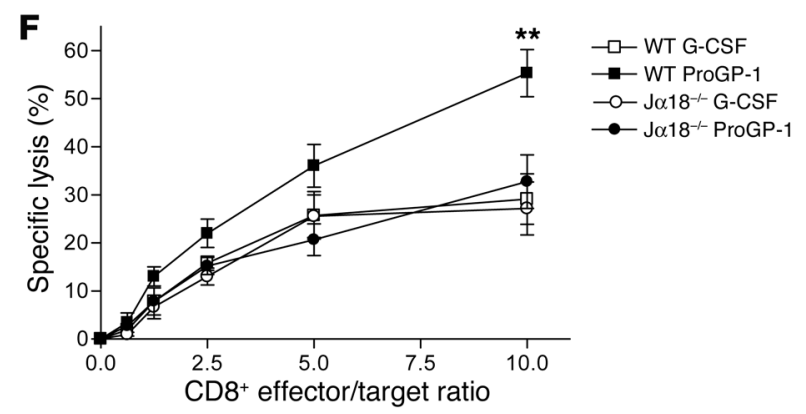

ProGP-1 enhances CD8 ${ }^{+}$T cell cytotoxicity following allogeneic SCT. (A) Irradiated B6D2F1 mice received whole spleen from donors mobilized with G-CSF or ProGP-1. In vivo cytotoxicity was determined as described in Methods (syngeneic, $n=3$ per group; allogeneic, $n=5$ per group). ${ }^{*} P=0.008 \mathrm{G}-\mathrm{CSF}$ allogeneic vs. ProGP-1 allogeneic. (B) At day 13 after SCT, whole spleen was utilized as the effector population in ${ }^{51} \mathrm{Cr}$-release CTL assays; host-type target, P815; donor-type target, EL4. ${ }^{* *} P<0.05$ vs. other groups. One of 2 identical experiments shown. (C) Irradiated B6D2F1 mice received whole spleen, CD4+- or CD8 $\beta^{+-}$depleted spleen, or CD4+- and CD8 $\beta^{+-}$depleted spleen from WT donors ( $n=9$ per group). Additional cohorts received whole spleen from J $\alpha 18^{-/-}$donors or CD4+-depleted spleen from WT donors supplemented with purified CD4+ $\mathrm{T}$ cells from WT or Ja18 $18^{-/}$donors ( $n=5$ per group). All donors were mobilized with ProGP-1. In vivo cytotoxicity was determined at day 12. ${ }^{\star \star} P<0.05$ vs. WT whole spleen. Combined data from 2 experiments shown. (D) CD8 ${ }^{+} T$ cells were sort-purified at day 13 from recipients of whole WT spleen, CD4 $4^{+}$-depleted spleen, or whole $\mathrm{J} \alpha 18^{-/}$spleen and utilized as effectors in ${ }^{51} \mathrm{Cr}$-release CTL assays. ${ }^{* \star} P<0.05$ WT nondepleted anti-host vs. WT CD4+-depleted anti-host or Ja18 ${ }^{-1-}$ anti-host. (E) Irradiated B6D2F1 mice received grafts from WT or Ja18 $1{ }^{--}$donors mobilized with G-CSF or ProGP-1; in vivo cytotoxicity index was determined at day 12 ( $n=6$ per group). \# $P=0.002$ WT ProGP-1 vs. Ja18 $18^{-/}$ProGP-1. (F) CD8 ${ }^{+}$T cells were sort-purified at day 13 and utilized as effectors in ${ }^{51} \mathrm{Cr}$-release CTL assays; P815 target population. ${ }^{* \star} P<0.05$ WT ProGP-1 vs. all other groups.

cytotoxicity against host or donor-type ${ }^{51}$ Cr-labeled class II ${ }^{+}$LPS blasts (Supplemental Figure 1C). In contrast to ProGP-1 however, cytotoxicity following mobilization with G-CSF was not dependent on the presence of NKT cells in vivo (Figure 2E) or ex vivo (Figure $2 \mathrm{~F})$. Thus, donor mobilization with ProGP- 1 increases $\mathrm{CD}^{+} \mathrm{T}$ cell cytotoxicity directed against host-type antigens, and maximal CD8 ${ }^{+}$ $\mathrm{T}$ cell-mediated cytotoxicity is dependent on the presence of both $\mathrm{CD} 4^{+} \mathrm{T}$ cells and double-negative NKT cells.
Donor mobilization with ProGP-1 effectively separates GVHD and GVL effects following allogeneic SCT. Since $\mathrm{CD}^{+} \mathrm{T}$ cell-mediated cytotoxicity is enhanced following donor mobilization with ProGP-1, we examined effects on leukemia clearance following allogeneic SCT. Lethally irradiated B6D2F1 mice received grafts consisting of whole spleen plus $1 \times 10^{4} \mathrm{P} 815\left(\mathrm{H}-2^{\mathrm{d}}\right)$. As previously described, recipients of grafts from control allogeneic donors die rapidly (median: 9 days) with characteristic features of GVHD (Fig- 

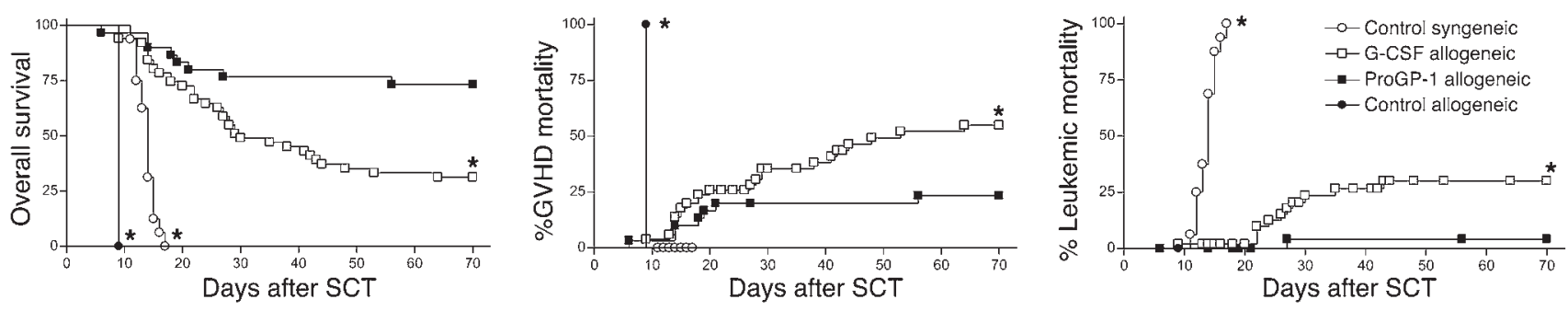

Figure 3

Donor mobilization with ProGP-1 effectively separates GVHD and GVL effects following allogeneic SCT. Irradiated B6D2F1 mice received spleen grafts from B6D2F1 (syngeneic) or C57BL/6 (allogeneic) donors mobilized with control diluent, G-CSF, or ProGP-1 as indicated. At the time of transplant, mice also received a leukemic challenge of $1 \times 10^{4} \mathrm{P} 815$. Overall survival and death due to leukemic progression or GVHD by Kaplan-Meier analysis are indicated (ProGP-1 allogeneic, $n=30$; G-CSF allogeneic, $n=51$; control allogeneic, $n=4$; control syngeneic, $n=16) .{ }^{*} P<0.05$ vs. ProGP-1.

ure 3) (23, 30). Mice receiving syngeneic grafts also died rapidly (median: 14 days) with evidence of progressive leukemia, regardless of mobilization with control diluent, G-CSF, or ProGP-1 (data for control diluent only shown). Following donor mobilization with G-CSF, overall survival at day 70 was $31 \%$, with death attributable to GVHD in 55\% and leukemic progression in 30\% by Kaplan-Meier analysis. In contrast, overall survival at day 70 in recipients of ProGP-1-mobilized grafts was $73 \%$, with $23 \%$ dying from GVHD and only $4 \%$ dying from leukemia $(P<0.05$ versus G-CSF). Thus, mobilization with ProGP-1 improved overall survival due to effective separation of GVHD and GVL effects.

ProGP-1-mobilized NKT cells enhance host DC activation and subsequent $C D 8^{+}$-dependent GVL effects. Since GVL effects following SCT are dependent on host APCs (35), we examined the expression of activation markers on host DCs following transplantation in the presence or absence of NKT cells. At 24 hours after SCT, more than $90 \%$ of Class $\mathrm{II}^{+} \mathrm{CD} 11 \mathrm{c}^{+}$DCs were of host origin (determined by lack of expression of the congenic donor marker CD45.1; data not shown). Expression of the activation molecules CD40, IL-12, IL-6, and TNF- $\alpha$ by host DCs was increased in recipients of WT NKT cell-replete ProGP-1-mobilized grafts (Figure 4A). These molecules are known to be regulated by IFN- $\gamma(36)$, which is produced in large amounts by ProGP-1-mobilized NKT cells following activation (Figure 1C).

Following allogeneic SCT and P815 challenge $\left(5 \times 10^{4}\right.$ cells per animal), recipients of $\mathrm{T}$ cell-depleted grafts from WT or J $18^{-/-}$ donors mobilized with ProGP-1 all died rapidly (median: 10 days) from progressive leukemia. GVL effects were essentially lost in recipients of T cell-replete J $\alpha 18^{-/-}$grafts but remained capable of reducing leukemic lethality in the majority of recipients of WT grafts (Figure 4B). To determine whether NKT cell activation via TCR ligation with $\alpha$-GalCer (C20:2) can also enhance cellular cytotoxicity after SCT, recipients of G-CSF-mobilized grafts received either $\alpha$-GalCer (C20:2) or control diluent on days 1 and 4 following transplantation. Cytotoxicity against host antigens was significantly increased following administration of $\alpha$-GalCer (C20:2), and this was dependent on the presence of both NKT cells and $\mathrm{CD}^{+} \mathrm{T}$ cells (Figure 4C).

Enhanced cellular cytotoxicity following mobilization with ProGP-1 is not attributable to Flt-3L signaling or the modulation of donor DCs. Donor mobilization with ProGP-1 results in significant expansion of CD11chi DCs, CD11c dim/B220hi DCs (30) and granulocyte-monocyte APC precursors with regulatory properties, termed GM cells (37). Both GM cells and CD11 $c^{+}$DCs are CD1 $d^{+}$(data not shown) and able to present ligands such as $\alpha$-GalCer (C20:2) to sort-purified NKT cells to induce IFN- $\gamma$ production (Figure $5 \mathrm{~A}$ ), suggesting these populations may be responsible for enhanced GVL effects after SCT. Depletion of CD $11 c^{+}$DCs from ProGP-1-mobilized grafts, however, did not impair cytotoxicity, and similarly, addition of GMs or CD11c $\mathrm{c}^{+}$DCs from a ProGP-1-mobilized graft to G-CSF-mobilized whole spleen grafts failed to enhance cytotoxicity (Figure 5B). Mobilization with a combination of G-CSF and Flt-3L also markedly increased CD11c $\mathrm{c}^{+}$DCs (Supplemental Figure 1D). In order to examine the contribution of Flt-3L to the enhancement of cytotoxicity and GVL effects seen following ProGP-1 mobilization, we next examined the combined mobilization with G-CSF and Flt-3L. In vivo cytotoxicity was not enhanced by the addition of Flt-3L to G-CSF during mobilization (Figure 5C), and following allogeneic SCT and leukemic challenge (P815), overall survival and leukemic progression were equivalent (Figure 5D).

Donor mobilization with pegylated G-CSF enhances NKT cell responses to TCR ligation and increases GVL effects. The protection from GVHD following stem cell mobilization with G-CSF is dose dependent and may also be enhanced via the augmentation of G-CSF activity by pegylation (23). As shown in Figure 6A, mobilization with pegylated G-CSF (Peg-G-CSF) expanded splenic type $1 \mathrm{NKT}$ cells and significantly increased functional responses to $\alpha$-GalCer (C20:2). While recipients of Peg-G-CSF-treated grafts had increased cytotoxicity after SCT that was dependent on the presence of type 1 NKT cells (Figure 6B), this effect could not be reproduced by escalating the dose of standard G-CSF administered to donors (Figure 6C). Following allogeneic SCT and leukemic challenge (P815), overall survival was improved in recipients of PegG-CSF-mobilized stem cell grafts (Supplemental Figure 1E) due to improved GVL effects (Figure 6D). Thus, augmentation of signaling via the G-CSF receptor is central to the enhanced cytotoxicity and GVL effects seen following mobilization with potent G-CSF analogs. It is important to note that donor NKT cells do not themselves regulate GVHD following stem cell mobilization with Peg-G-CSF since in separate experiments without leukemic challenge, GVHD mortality in recipients of WT grafts was significantly increased relative to recipients of NKT cell-deficient grafts (GVHD mortality at day 35 in recipients of Peg-G-CSF-mobilized J $\alpha 18^{-/-}$ vs. WT grafts, $6 \%$ vs. $44 \% ; P<0.02$; data not shown).

Enhanced $C D 8^{+}$cytotoxicity following mobilization with ProGP-1 is mediated via the perforin pathway. To determine the pathways responsible for the enhanced cytotoxicity observed following mobilization with ProGP-1, lethally irradiated mice received 

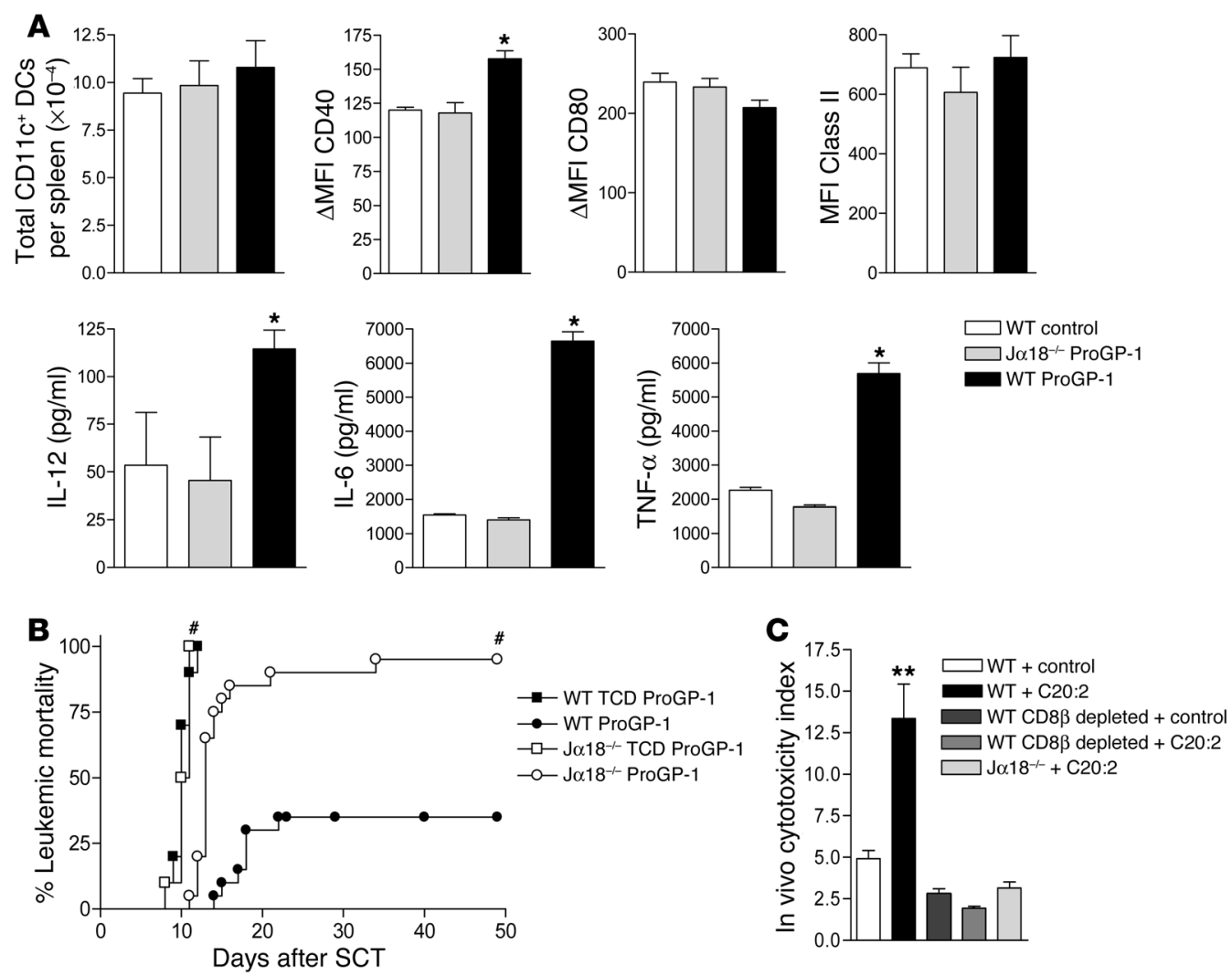

Figure 4

ProGP-1-activated NKT cells enhance host DC activation and subsequent CD8+-dependent GVL effects. (A) Irradiated B6D2F1 mice received whole spleen grafts from WT or Ja18 ${ }^{-/-}$donors mobilized with control diluent or ProGP-1. Total splenic DC numbers and costimulatory molecule expression were determined 24 hours after SCT. Purified DCs were stimulated as described in Methods and supernatant cytokine production determined by ELISA. Data presented as mean \pm SEM. Change in MFI calculated as follows for individual samples: MFI-conjugated antibody of interest - MFI-conjugated isotype control. Data for Class II expression presented as MFI only. ${ }^{\star} P \leq 0.05$ vs. other groups. Combined data from 2 experiments shown. (B) Irradiated B6D2F1 mice received whole spleen ( $n=20$ per group) or T cell-depleted (TCD) spleen ( $n=10$ per group) from WT or Ja18 $18^{-/}$donors mobilized with ProGP-1. At the time of transplant, mice also received a leukemic challenge of $5 \times 10^{4} \mathrm{P} 815$ cells. Leukemia death analyzed by Kaplan-Meier analysis. $\# P<0.0001$ vs. WT nondepleted grafts. Combined data from 2 experiments shown. (C) Irradiated B6D2F1 mice received whole spleen from WT or J $\alpha 18^{-/-}$donors or CD8 $\beta$-depleted spleen from WT donors. All donors were mobilized with G-CSF. At days 1 and 4 following transplantation, recipients also received either $\alpha$-GalCer (C20:2) or vehicle as indicated. In vivo cytotoxicity index determined at day $12\left(n=10\right.$ per group except Ja18 $\left.{ }^{-1-}+\mathrm{C} 20: 2, n=5\right)$. Combined data from 2 identical experiments shown. ${ }^{\star \star} P<0.01$ vs. other groups.

grafts from WT donors or donors deficient in perforin, TNF- $\alpha$, TNF-related apoptosis-inducing ligand (TRAIL), or FasL. As shown in Figure 7A, ProGP-1 mobilization of donors resulted in significantly superior cytotoxicity except when donors were perforin deficient. The absence of anti-host cytotoxicity in recipients of perforin-deficient grafts was confirmed using ${ }^{51} \mathrm{Cr}$-release assays (Figure 7B). Phenotyping of spleen following SCT confirmed that loss of cytotoxicity in recipients of perforin ${ }^{-/}$grafts was not due to impaired CD8 ${ }^{+} \mathrm{T}$ cell reconstitution (Figure $7 \mathrm{C}$ ). In order to determine whether cytotoxic pathways additional to those studied were also invoked by ProGP-1 mobilization, purified CD8 ${ }^{+} \mathrm{T}$ cells from SCT recipients of perforin-deficient grafts were used as effectors in the highly sensitive fluorolysis assay, which measures relative cell death over a prolonged 48-hour period. Although cytotoxic pathways other than perforin contribute to GVL activity $(18,38)$ and perforin-independent cytotoxicity against allogeneic targets was detectable in the fluorolysis assay (Figure 7D), there were no significant differences attributable to donor mobilization with G-CSF or ProGP-1. Thus, the enhanced cytotoxicity following ProGP-1 mobilization is solely mediated through the perforin pathway.

\section{Discussion}

Stem cell mobilization with G-CSF reduces the capacity of T cells to induce acute GVHD on a per cell basis in preclinical models $(15,23,30,39)$. In clinical practice, despite a 10 -fold increase in the number of donor $\mathrm{T}$ cells transferred to recipients of G-CSFmobilized peripheral blood stem cells rather than bone marrow grafts, the incidence of acute GVHD is not increased (40-45). The ability of cytokines to induce regulatory $\mathrm{T}$ cells in vivo has been established $(23,46,47)$, and we have recently demonstrated that donor mobilization with ProGP-1 promotes the generation of a regulatory APC population (termed GM cells) and subsequently IL-10-producing $\mathrm{CD}^{+}{ }^{+}$regulatory $\mathrm{T}$ cells $(37)$. The present data demonstrate that ProGP-1 mobilization also augments NKT cell number and function, promoting NKT cell-dependent host 


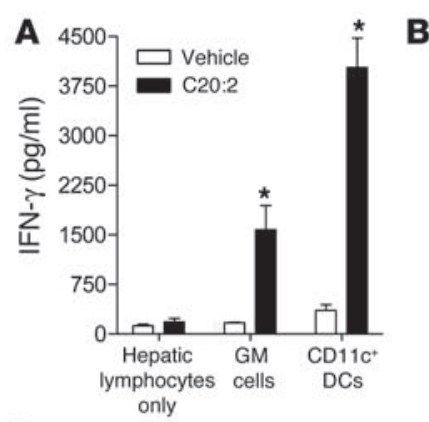

D
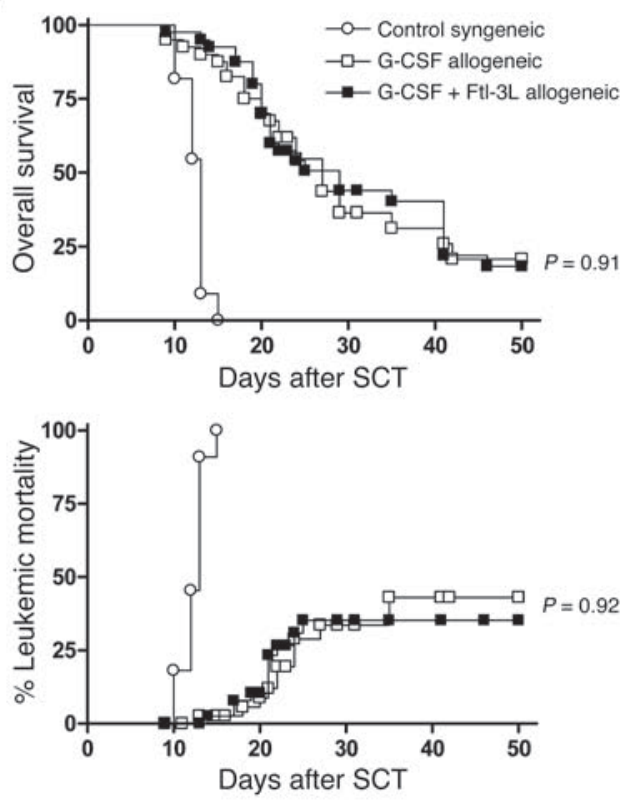
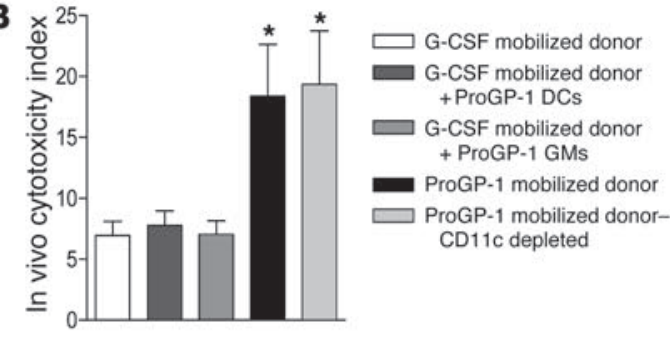

Day 8

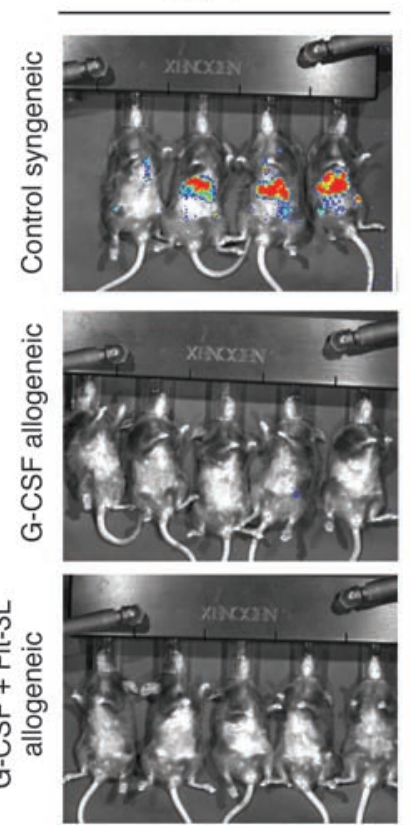

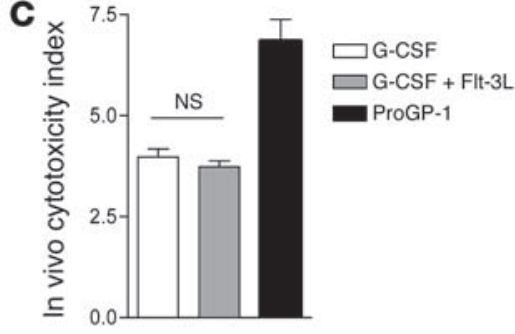

Day 17

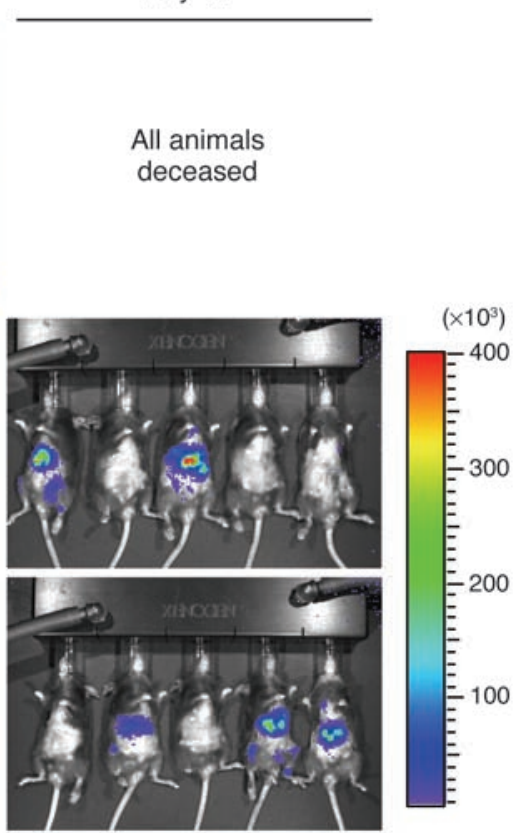

Figure 5

Enhanced cellular cytotoxicity following donor pretreatment with ProGP-1 is not attributable to Flt-3L signaling or the modulation of donor DCs. (A) GM cells and DCs from ProGP-1-mobilized WT C57BL/6 donors were cultured with nonmobilized C57BL/6 hepatic lymphocytes plus control diluent or $\alpha$-GalCer (C20:2). ${ }^{*} P<0.05$ vs. control. One of 2 identical experiments shown. (B) Irradiated B6D2F1 mice received whole spleen from WT donors mobilized with G-CSF or ProGP-1. Additional cohorts received whole G-CSF-mobilized spleen plus purified GMs or DCs from a ProGP-1-mobilized donor or ProGP-1-mobilized spleen depleted of CD11 $\mathrm{C}^{+}$DCs. In vivo cytotoxicity index determined at day 12 (G-CSF-mobilized donors, $n=9$; G-CSF-mobilized donors + ProGP-1 DCs, $n=9$; G-CSF-mobilized donors + ProGP-1 GM, $n=5$; ProGP-1mobilized donors, $n=4$; ProGP-1-mobilized donors CD11c depleted, $n=4)$ ) ${ }^{*} P<0.01$ vs. G-CSF-mobilized groups. (C) Irradiated B6D2F1 mice received whole spleen from WT donors mobilized with G-CSF, G-CSF + Flt-3L, or ProGP-1 as described in Methods. In vivo cytotoxicity index determined at day 12 ( $n=4$ per group). (D) Irradiated B6D2F1 mice received whole spleen from B6D2F1 or C57BL/6 donors mobilized with G-CSF or G-CSF + Flt-3L. At the time of transplant, mice also received a leukemic challenge of $1 \times 10^{4}$ luciferase-transfected P815 cells. Overall survival by Kaplan-Meier analysis (control syngeneic, $n=11$; other groups, $n=40$ ). Representative Xenogen images at days 8 and 17 as described in Methods.

DC activation and donor $\mathrm{CD}^{+} \mathrm{T}$ cell perforin-restricted cellular cytotoxicity, effectively separating GVHD and GVL effects.

The roles of NKT cells in leukemia eradication following SCT have not, to our knowledge, previously been examined. In the present study, increased cytotoxicity following ProGP-1 mobilization was absolutely dependent on the presence of $\mathrm{CD}^{+} \mathrm{T}$ cells, but maximal effects were also dependent on the presence of $\mathrm{CD}^{+} \mathrm{T}$ cells and NKT cells. Although cytokine-mediated $\mathrm{CD}^{+} \mathrm{T}$ cell help for $\mathrm{CD}^{+} \mathrm{T}$ cell cytotoxicity is well recognized (48), the NKT cell-mediated enhancement of GVL effects is, we believe, a new finding. Production of IFN- $\gamma$ by NKT cells following $\alpha$-GalCer stimulation is required for antitumor effects (49), and both $\mathrm{CD}^{+} \mathrm{T}$ cells and NKT cells have been shown to be necessary for clearance of an established tumor in a transgenic mouse system (50). Activated NKT cells therefore provide a central point through which the innate and adaptive immune systems may be bridged via the promotion of DC maturation (51) and priming of MHC class I-restricted CD8 ${ }^{+} \mathrm{T}$ cells (52-54). Our data now demonstrate that donor mobilization with potent G-CSF analogs provides an effective mechanism to enhance these NKT cell-dependent effects and increase GVL effects. The role of NK1.1 $\mathrm{T}$ cells in GVHD was previously studied in a model of allogeneic bone marrow transplantation. Zeng and colleagues demonstrated that the adoptive transfer of bone marrow- but not peripheral blood-derived NK1.1 $1^{+} \mathrm{T}$ cells suppresses GVHD. However, this study was prior to the more specific clas- 

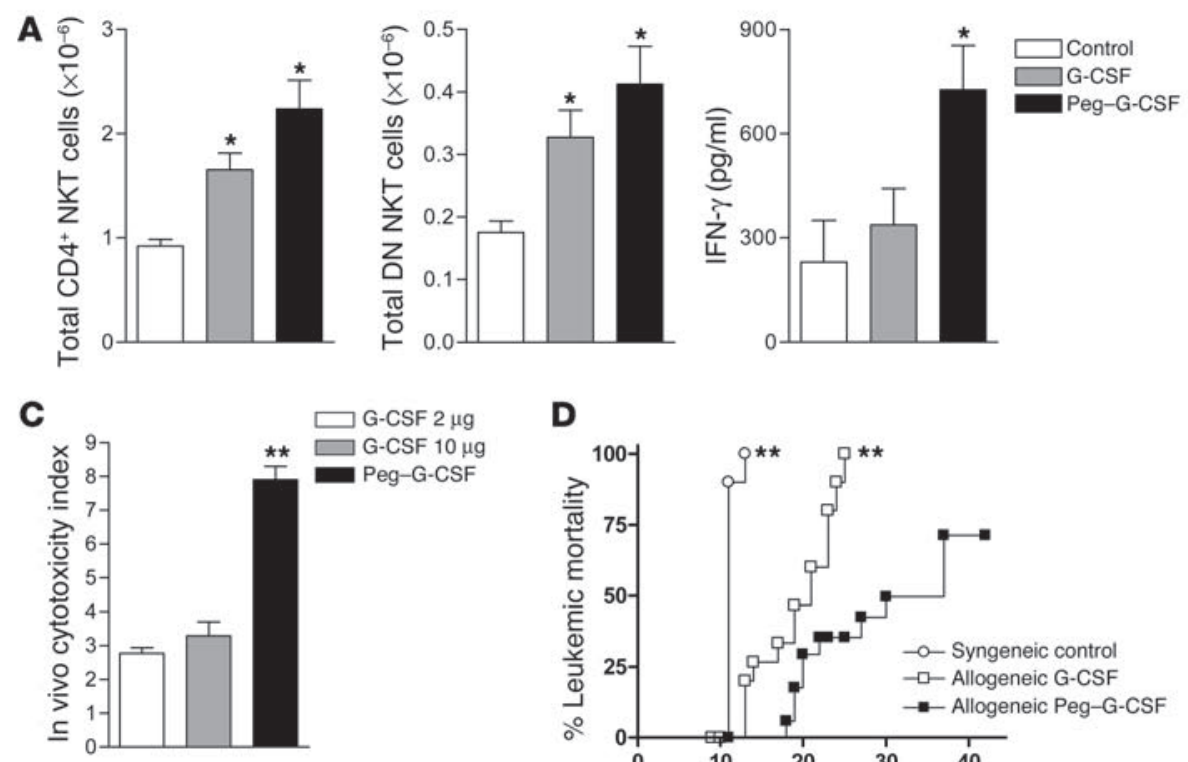

D

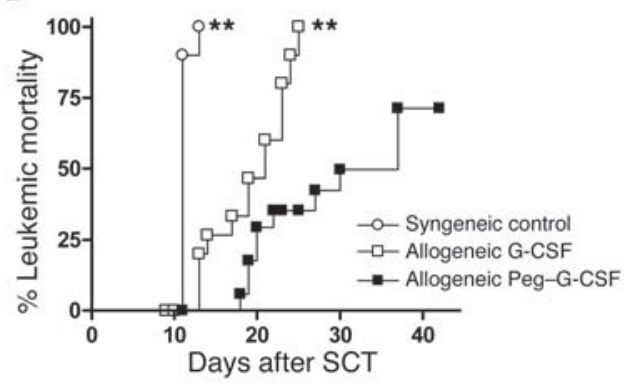

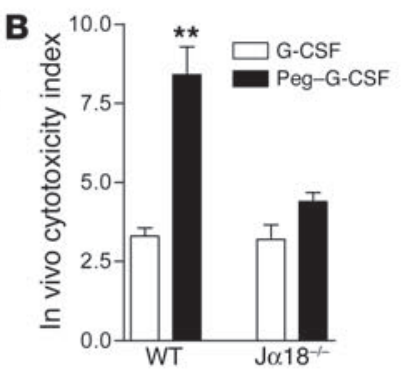

Day 20

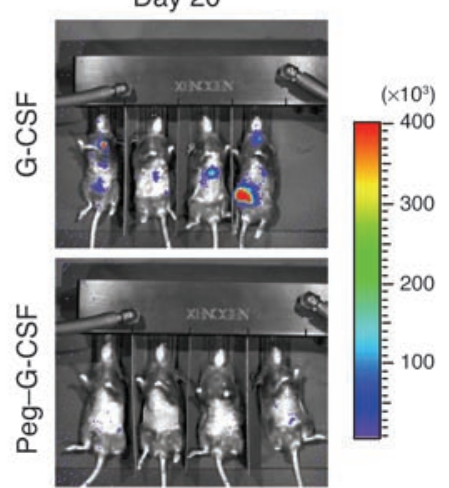

\section{Figure 6}

Donor mobilization with Peg-G-CSF expands type 1 NKT cells, enhances in vitro responses to $\alpha$-GalCer, and increases GVL effects. (A) C57BL/6 mice received control, G-CSF $2 \mu \mathrm{g} /$ animal/day from days -6 to -1 , or Peg-G-CSF $12 \mu \mathrm{g} /$ animal on day -6 only ( $n=8 \mathrm{per}$ group). Whole spleen was then cultured with $\alpha$-GalCer (C20:2) and supernatant IFN- $\gamma$ determined by cytokine bead array after 24 hours. ${ }^{*} P<0.05$ vs. control. Combined data from 2 experiments shown. (B) Irradiated B6D2F1 mice received whole spleen from WT or Ja18 ${ }^{-/-}$donors mobilized with G-CSF $2 \mu \mathrm{g} / \mathrm{animal} / \mathrm{day}$ from days -6 to -1 or Peg-G-CSF $12 \mu \mathrm{g} /$ animal on day -6 only. In vivo cytotoxicity index determined at day 12 (WT G-CSF, $n=14$; WT Peg-G-CSF, $n=10$; other groups, $n=5$ ). ${ }^{\star \star} P<0.01$ vs. other groups. (C) Irradiated B6D2F1 mice received whole spleen from C57BL/ 6 donors mobilized with G-CSF $2 \mu \mathrm{g} /$ animal/day from days -6 to -1 , G-CSF $10 \mu \mathrm{g} /$ animal/day from days -6 to -1 , or Peg-G-CSF $12 \mu \mathrm{g} / \mathrm{animal}$ on day -6 only. In vivo cytotoxicity index determined at day 12 ( $n=6$ per group). ${ }^{* *} P<0.01$ vs. other groups. (D) Irradiated B6D2F1 mice received whole spleen from B6D2F1 or C57BL/6 donors mobilized with G-CSF $2 \mu \mathrm{g} / \mathrm{animal} / \mathrm{day}$ from days -6 to -1 or Peg-G-CSF $12 \mu \mathrm{g} / \mathrm{animal}$ on day -6 only. At the time of transplant, mice also received a leukemic challenge of $5 \times 10^{4}$ luciferase-transfected P815 cells. Leukemia-free survival by Kaplan-Meier analysis (syngeneic control, $n=8$; other groups, $n=18$ ). ${ }^{* \star} P<0.01 \mathrm{vs}$. Peg-G-CSF. Representative Xenogen images at day 20 shown.

sification of NKT cell subsets in which at least 2 populations of CD1d-restricted NKT cells are now recognized to exist. The most prevalent and extensively studied are type 1 (or semi-invariant) NKT cells, which express a semi-invariant TCR (in the mouse consisting of a V $\alpha 14 \mathrm{~J} \alpha 18$ TCR- $\alpha$ chain, preferentially paired with either V $\beta 8, V \beta 7$, or V $\beta 2$ ), and are $\alpha$-GalCer-loaded CD1dtetramer positive (1). Other CD1d-restricted NKT cells have been identified (55) that express a more diverse TCR repertoire and have been referred to as type II NKT cells (1). Since the NK1.1 ${ }^{+} \mathrm{T}$ cell populations in earlier studies are likely to contain a mixture of subtypes (including CD1d-independent NKT-like cells), it is difficult to determine effects of type 1 NKT cells in isolation from this work (6). Nevertheless, it strongly suggests the existence of an NKT cell population within the bone marrow with regulatory properties that is absent in the peripheral blood. In a model of allogeneic transplantation following sublethal irradiation, Morecki and colleagues reported that stimulation of NKT cells with $\alpha$-GalCer following transplantation prevented GVHD (56). This may reflect the stimulation of host NKT cells with $\alpha$-GalCer, which has been shown to attenuate GVHD via Th2 polarization of donor $\mathrm{T}$ cells (57). Although there is a reduction in GVHD following stem cell mobilization with potent
G-CSF analogs, this effect is independent of NKT cells, since GVHD lethality was further reduced in the absence of NKT cells. Therefore, following stem cell mobilization with potent G-CSF analogs, regulatory T cell (23) and APC populations (37) within the donor inoculum compensate for the effect of enhanced CTL priming on GVHD that is driven by donor NKT cells.

ProGP-1 stimulates both G-CSF and Flt-3L receptors and dramatically expands DCs $(27,28)$. Since host APCs are required for both GVHD (58) and GVL effects (35), we considered whether enhanced cross presentation of host antigens by expanded donor APCs may contribute to the enhanced GVL effects observed. Surprisingly, neither Flt-3L signaling nor associated effects on donor APCs influenced in vivo cytotoxicity or GVL effects. Mobilization with Peg-G-CSF, however, also resulted in increased in vivo cellular cytotoxicity following SCT, which was again NKT cell dependent. Matte and colleagues recently reported that donor APCs are not required for CD8-mediated GVL effects in a murine model of donor lymphocyte infusion and chronic myeloid leukemia (59). Thus, enhanced GVL effects following mobilization with ProGP-1 appear to be attributable to signaling via the G-CSF receptor and subsequent effects on NKT cells rather than the Flt-3L receptor or associated effects on donor APCs. 
A
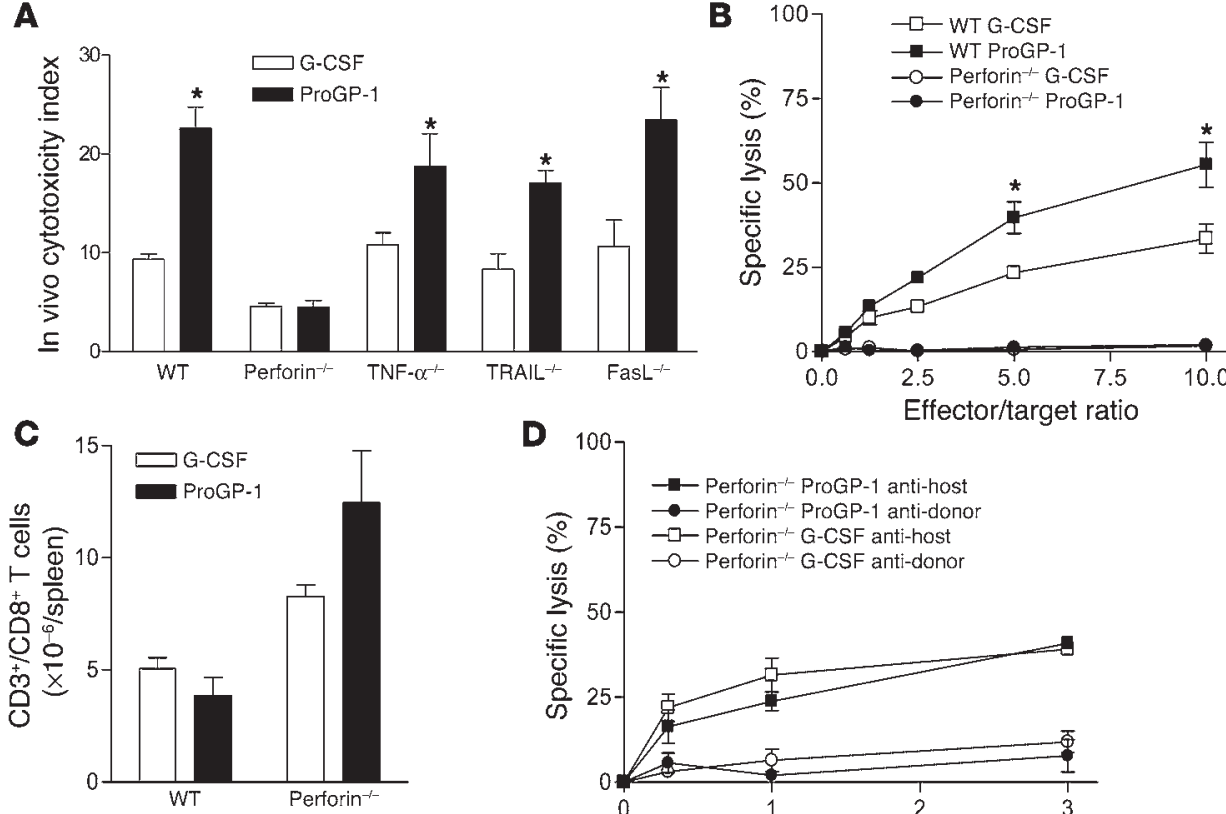

Figure 7

The enhanced cytotoxicity observed following donor pretreatment with ProGP-1 is mediated solely via the perforin pathway. (A) Irradiated B6D2F1 mice received whole spleen from WT, Perforin ${ }^{-1-}, \mathrm{TNF}^{-/-}$, TRAIL $^{-1}$, or FasL ${ }^{-1}$ donors mobilized with G-CSF or ProGP-1. In vivo cytotoxicity index was determined at day 12 ( $n=4$ per group). ${ }^{*} P<0.05$ ProGP-1 vs. G-CSF within matched donor groups. (B) CD8 ${ }^{+} \mathrm{T}$ cells were sort-purified at day 13 from recipients of WT or Perforin ${ }^{-1}$ spleen and utilized as effectors in ${ }^{51} \mathrm{Cr}$-release CTL assays; P815 target population. ${ }^{*} P<0.05$ WT ProGP-1 vs. all other groups. (C) Total CD8 ${ }^{+}$T cells per spleen at day 13 after transplant ( $n=4$ per group). (D) CD8 ${ }^{+}$T cells were sort-purified at day 13 from recipients of Perforin ${ }^{-/-}$spleen and utilized as effectors in fluorolysis CTL assays as described in Methods. Host-type target, P815; donor-type target, EL4.

Enhanced signaling via the G-CSF receptor may directly or indirectly induce NKT cell expansion and functional changes. NKT cells are expanded in G-CSF transgenic mice (32), and G-CSF receptor mRNA has been demonstrated in NKT-like cells (60). Yanagisawa and colleagues demonstrated that impaired proliferative responses of $\mathrm{V} \alpha 24$ NKT cells to $\alpha$-GalCer in patients with malignancies could be restored following ex vivo culture with G-CSF (61). In our studies, however, the degree of cellular cytotoxicity following stem cell mobilization with standard G-CSF was not dependent on the presence of type 1 NKT cells. Thus, molecular alterations in the new G-CSF moieties appear to result in the augmentation of signaling that profoundly influences NKT cell expansion and function. In clinical practice, mobilization with G-CSF is not associated with modulation of NKT cell function, and NKT cells are not expanded in G-CSF-mobilized stem cell grafts from healthy donors $(62,63)$. Although recent studies have examined NKT cell reconstitution following allogeneic SCT (64), functional modulation of NKT cells and effects on GVHD or leukemia eradication remain to be determined in a clinical setting.

We propose, therefore, that donor mobilization with potent G-CSF analogs promotes expansion and activation of type 1 NKT cells, which produce large amounts of IFN- $\gamma$ following activation. Following transplantation, NKT cells may thus be activated by either antigen (presented by host or donor CD $1 \mathrm{~d}^{+}$ APCs) or cytokine stimulation (e.g., IL-12, IL-18) (65-67), leading to the generation of large amounts of IFN- $\gamma$ that promote early host DC activation and $\mathrm{CD}^{+}$ $\mathrm{T}$ cell priming (52-54). Although enhanced host DC activation and CTL priming may be expected to increase GVHD, we have previously shown that mobilization with PegG-CSF or ProGP-1 attenuates $\mathrm{CD}^{+} \mathrm{T}$ cell-mediated GVHD (23, 30). Mobilization with Peg-G-CSF induces the generation of IL-10producing regulatory $\mathrm{T}$ cells prior to transplantation, which subsequently regulate GVHD (23). We have also recently demonstrated that ProGP-1 and G-CSF expand a GM precursor population that differentiates into CD40 ${ }^{\text {neg }} \mathrm{APC}$ following transplantation and that these cells promote the generation of MHC class II-restricted antigenspecific IL-10-secreting regulatory $\mathrm{T}$ cells (37). Thus, these cytokines regulate CD4-dependent GVHD responses via effects on $\mathrm{T}$ cells within the donor prior to SCT in addition to effects on donor APC and subsequent regulatory $\mathrm{T}$ cell generation after SCT. Regulatory $\mathrm{T}$ cells have been shown to prevent GVHD (68-70) without impairing GVL effects $(25,26)$. Mobilization with potent G-CSF analogs thus allows concurrent enhancement of NKT cell number and activity, promoting host DC activation and subsequent CD8-dependent GVL effects while promoting the generation of regulatory $T$ cells preventing CD4-dependent GVHD. This provides a therapeutic strategy to allow allogeneic hemopoietic transplantation across MHC barriers while enhancing immunological tumor clearance, potentially greatly expanding the applicability of allogeneic SCT.

\section{Methods}

Mice. Female C57BL/6 (H-2 $\left.{ }^{\mathrm{b}}, \mathrm{CD} 45.2^{+}\right)$, B6 PTPRC ${ }^{\mathrm{A}}\left(\mathrm{H}-2^{\mathrm{b}}, \mathrm{CD} 45.1^{+}\right)$, and $\mathrm{B} 6 \mathrm{D} 2 \mathrm{~F} 1\left(\mathrm{H}-2^{\mathrm{b} / \mathrm{d}}, \mathrm{CD} 45.2^{+}\right)$mice were purchased from the Animal Resources Centre. C57BL/6 Jo18-/-, perforin ${ }^{-/-}$, $\mathrm{TNF}^{-/-}$, TRAIL ${ }^{-/}$(kindly provided by Jacques Peschon, AMGEN, Seattle, Washington, USA), and FasL $\mathrm{L}^{-/}$mice as described $(49,71)$ (backcrossed for at least 10 generations to C57BL/6) were supplied by the Australian National University and The Peter MacCallum Cancer Centre. Mice were housed in sterilized microisolator cages and received acidified autoclaved water ( $\mathrm{pH} 2.5)$ after transplantation.

Cytokine mobilization. Cytokines were diluted in $0.9 \%$ normal saline and injected subcutaneously as follows: ProGP-1 (Pharmacia), 20 gg/animal, days -10 to -1 ; recombinant human Peg-G-CSF (Amgen Inc.), $12 \mu \mathrm{g} /$ animal, day -6 only; recombinant human G-CSF (Amgen Inc.), $10 \mu \mathrm{g} / \mathrm{animal}$, days -10 to -1 (for G-CSF vs. ProGP-1) or $2 \mu \mathrm{g} /$ animal, days -6 to -1 (for G-CSF vs. Peg-G-CSF); Flt-3L (Pharmacia), $10 \mu \mathrm{g} / \mathrm{animal} /$ day, days -10 to -1 (in combination with G-CSF, $10 \mu \mathrm{g} / \mathrm{animal} /$ day, days -10 to -1 ). Donor spleens were harvested on day 0 .

SCT. Mice were transplanted as described previously $(23,30)$. In brief, on day -1, B6D2F1 mice received 1100 cGy total body irradiation $\left({ }^{137} \mathrm{Cs}\right.$ source 
at $108 \mathrm{cGy} / \mathrm{min}$ ) split into 2 doses separated by 3 hours to minimize gastrointestinal toxicity. Donor splenocytes, corrected to administer equivalent numbers of $\mathrm{CD}^{+} \mathrm{T}$ cells, were injected intravenously on day 0 . Animal procedures were undertaken using protocols approved by the Queensland Institute of Medical Research animal ethics committee. Transplanted mice were monitored daily, and those with GVHD clinical scores of 6 or greater were sacrificed and the date of death registered as the next day in accordance with institutional animal ethics committee guidelines.

$\alpha$-GalCer. In experiments examining the effects of $\alpha$-GalCer stimulation, we utilized a newly described form of $\alpha$-GalCer that contains a C20 diunsaturated fatty acid (C20:2 (cis, cis-11,14) eicosadienoic acid). In other respects, the structure of this $\alpha$-GalCer (here referred to as C20:2) is identical to the previously described $\alpha$-GalCer KRN7000. The C20:2 compound has been shown to be a potent and more specific activator of murine NKT cells when compared with KRN7000 (72). Lyophilized C20:2 was reconstituted in a $0.5 \%$ solution of $\mathrm{PBS} / 20 \%$ Tween- 20 at a final concentration of $500 \mu \mathrm{M}$. In vitro $\alpha$-GalCer stimulation was at a final concentration of $10 \mathrm{ng} / \mathrm{ml}$. In vivo, intraperitoneal $\alpha$-GalCer at $2 \mu \mathrm{g} /$ animal was administered on days 1 and 4 after SCT.

$T$ cell depletion. Splenocytes were depleted of either all $\mathrm{T}$ cells or specific $\mathrm{T}$ cell subtypes for individual experiments. For total $\mathrm{T}$ cell depletion, splenocytes were incubated with hybridoma supernatants containing anti-CD8 (TIB211) and anti-Thy1.2 (HO-13-4) monoclonal antibodies followed by incubation with rabbit complement (Cedarlane Laboratories Ltd.) as previously described (30). Resulting cell suspensions contained less than $1 \%$ contamination of viable $\mathrm{T}$ cells. In some experiments, splenocytes were depleted of $\mathrm{CD}^{+} \mathrm{T}$ cells, $\mathrm{CD} 8 \beta^{+} \mathrm{T}$ cells, or both. Splenocytes were incubated with purified anti-CD4 (GK1.5) or anti-CD8 $\beta$ (H35-17.2) followed by goat anti-rat IgG microbeads (Miltenyi Biotec) and MACS column magnetic separation. Resulting cell suspensions contained less than $1 \%$ contamination of the relevant phenotype.

Assessment of GVHD. The degree of systemic GVHD was assessed by scoring as previously described (maximum index $=10)(18,73-75)$.

Leukemia challenge. The mastocytoma cell line, P815 (H-2d, CD45.2 $)$, derived from DBA-2 mice, was injected intravenously into B6D2F1 recipients on day 0 of transplantation at doses as indicated. Survival and clinical scores were monitored daily, and the cause of death (determined by postmortem examination) established as GVHD or leukemia. Leukemic death was defined by Xenogen imaging or the occurrence of either macroscopic tumor nodules in the liver or spleen, or hind-limb paralysis. GVHD death was defined by the presence of clinical signs of GVHD, assessed by the clinical scoring system, and the absence of leukemia. At the time of death from leukemia, GVHD survival data for an individual animal is censored at that time point and vice versa. Data were analyzed using the product limit method of Kaplan and Meier and survival curves compared using the log rank test (GraphPad Prism 4; GraphPad Software).

Xenogen imaging. In vivo imaging was performed as previously described (76) using an IVIS Imaging System (Xenogen). Mice were anesthetized with isoflurane and received $0.5 \mathrm{mg}$ luciferin (Xenogen) subcutaneously. Mice were imaged 5 minutes later for 1 minute. Pseudo-color images showing the whole-body distribution of bioluminescent signal (photons/second/ $\mathrm{cm}^{2} /$ steer radiant) were superimposed on conventional grayscale images.

CFSE labeling. CFSE labeling of $\mathrm{T}$ cells was performed as previously described (77). In brief, splenocytes were suspended at a density of $3 \times 10^{7}$ cells $/ \mathrm{ml}$, and CFSE (Invitrogen Corp.) was added at a final concentration of $2 \mu \mathrm{M}$. Cells were incubated at $37^{\circ} \mathrm{C}$ for 10 minutes and washed.

In vivo cytotoxicity index. At day 12 after SCT, recipient mice received an intravenous inoculum by tail vein injection containing $20 \times 10^{6}$ congenic donor-type PTPRC ${ }^{A}\left(\mathrm{H}-2^{\mathrm{b}}\right.$, CD45.1 $\left.1^{+}\right)$unlabeled splenocytes and $20 \times 10^{6}$ host-type B6D2F1 (H-2 $\left.{ }^{\mathrm{b} / \mathrm{d}}, \mathrm{CD} 45.2^{+}\right)$CFSE labeled splenocytes. Eighteen hours later, animals were bled, erythrocytes lysed by hypotonic shock, and peripheral blood leukocytes stained with PE-conjugated anti-CD45.1. The proportions of remaining CD45.1 ${ }^{+}$and CFSE-labeled cells were determined by FACScan (BD Biosciences) and an index of in vivo cytotoxicity (measuring the in vivo cytotoxic response to host-type targets while correcting for nonspecific loss of donor-type targets) defined as the percentage of remaining syngeneic $\mathrm{CD} 45.1^{+}$cells divided by the percentage of remaining allogeneic $\mathrm{CFSE}^{+}$cells.

Chromium 51-release assay. Targets were labeled with chromium $51\left({ }^{51} \mathrm{Cr}\right)$ as previously described (78). Target cells (host-type P815, H-2d; donor-type $\mathrm{EL} 4, \mathrm{H}-2^{\mathrm{b}}$ ) were cultured with donor $\mathrm{CD}^{+}$effectors, purified from the spleen of recipients 14 days after SCT for 5 hours at $37^{\circ} \mathrm{C}$ and $5 \% \mathrm{CO}_{2}$, and ${ }^{51} \mathrm{Cr}$ release into supernatants was determined via gamma counter (TopCount Microplate Scintillation Counter; Packard Instrument Co.). Spontaneous release was defined from wells receiving targets only and total release from wells receiving targets plus $1 \%$ Triton X-100. Percentage cytotoxicity was calculated as follows: $\%$ cytotoxicity $=($ experimental release - spontaneous release)/(total release - spontaneous release) $\times 100$.

Fluorolysis assay. Fluorolysis cytotoxicity assays were performed as previously described (79). In brief, P815 and EL4 target cells, stably transfected with a plasmid expressing the enhanced green fluorescent protein (EGFP) gene, were incubated with $\mathrm{CD}^{+} \mathrm{T}$ cells purified from the spleen of recipients 14 days after SCT for 48 hours. The degree of target cell lysis was measured by flow cytometry to count the number of viable propidium iodide-negative, EGFP-positive cells, whose numbers were standardized to a reference number of fluorochrome-linked beads. Percentage of lysis was calculated as follows: (1 - (experimental targets remaining/targets remaining in wells receiving targets only) $) \times 100$.

Hepatic lymphocyte and NKT cell isolation. Donor mice were sacrificed and livers perfused in situ with 5-10 $\mathrm{ml}$ of cold PBS via the hepatic portal vein. Livers were then removed and homogenized and lymphocytes isolated by room temperature isotonic Percoll density centrifugation (Amersham Biosciences) per manufacturer's instructions. NKT cells were FACS sorted (MoFlo, DakoCytomation) as the positive staining population following staining with TCR-FITC and NK1.1-PE within the CD11b-PE-Cy5 and 7-aminoactinomycin $\mathrm{D}$ (eBioscience) negative population. At the end of sorting, more than $85 \%$ of the cells were $\mathrm{TCR}^{+} \mathrm{NK} 1.1^{+}$.

$D C$ and GM cell isolation and stimulation. DC purification was undertaken as previously described (80). In brief, low-density cells were selected from digested spleen by nycodenz density gradient $(1.077 \mathrm{~g} / \mathrm{l})$ centrifugation. Non-DC-lineage cells were depleted by coating with rat IgG antibodies to B cells (CD19), T cells (CD3, Thy1), granulocytes (Gr-1), and erythroid cells (Ter-119). The coated cells were then removed by anti-rat IgG-conjugated magnetic beads (Invitrogen Corp.). At the end of this procedure, $50-70 \%$ of cells were DCs (class $\mathrm{II}^{+} / \mathrm{CD} 11 \mathrm{c}^{+}$), and $30-50 \%$ were GM cells. GM cells were FACS sorted (MoFlo, DakoCytomation) as the negative staining population following staining with CD11c-FITC and PE-conjugated lineage antibodies (B220, CD19, CD3). At the end of sorting, more than $95 \%$ of the cells were negative for CD11c and lineage markers. DCs were sorted as the $\mathrm{CD} 11 \mathrm{c}^{\text {hi }} \mathrm{B} 220^{\text {neg }}$ population to greater than $90 \%$ purity. Purified DCs were stimulated with LPS $(1 \mu \mathrm{g} / \mathrm{ml})$ and phosphorothioated oligo CpG $(1668,0.5 \mu \mathrm{M})(81)$.

In vitro NKT cell stimulation. Whole spleen or sort-purified hepatic NKT cells plus purified GM cells or DCs were cultured in the presence of the $\alpha$-GalCer analog C20:2 at a final concentration of $10 \mathrm{ng} / \mathrm{ml}$, or control diluent.

FACS analysis. The following $\mathrm{mAbs}$ were purchased from $\mathrm{BD}$ Biosciences - Pharmingen: FITC-conjugated Gr1 (RB6-8C5), CD11b (M1/70), CD31 (clone 390), CD45.2 (clone 104) and IgG2a isotype control; PE-conjugated CD3 (2C11), CD4 (GK1.5), CD8 $\alpha$ (53-6.7), CD11b (M1/70), CD11c (HL3), CD19 (1D3), CD40 (3/23), CD45.1 (A20), CD45R/B220 (RA3-6B2), CD80 
(16-10A1), CD86 (GL1), I-A/I-E (2G9), IgG2b isotype control; biotinylated CD45.1 and Gr1 and IgG2a isotype control. FITC-anti-mouse I-A/ I-E (M5/114.15.2) was from BioLegend. Streptavidin-PE-Cy5 was from DakoCytomation. Purified mAb against CD3 (KT3), CD19 (HB305), Gr1 (RB6-8C5), Thy1.2 (HO-13-4), Ter119, FcyR II/III (2.4G2), and biotinylated F4/80 were produced in house. PE-labeled, $\alpha$-GalCer-loaded or -unloaded (control) mCD1d tetramers were generated (by D.G. Pellicci) as previously described $(82,83)$.

Cytokine analysis. IFN- $\gamma$, IL-6, IL-12, and TNF- $\alpha$ were determined using the BD Cytometric Bead Array system (BD Biosciences - Pharmingen). All assays were performed according to the manufacturer's protocol.

Statistics. Survival curves were plotted using Kaplan-Meier estimates and compared by log-rank analysis. The Mann-Whitney $U$ test was used for the statistical analysis of cytokine data and clinical scores. $P<0.05$ was considered statistically significant. Data is presented as mean \pm SEM.

\section{Acknowledgments}

This work was supported in part by grants from the National Health and Medical Research Council (NHMRC), Australia, and the Queensland Cancer Fund. G.R. Hill is a Welcome Trust senior overseas research fellow. M.J. Smyth, D.G. Pellicci, and D.I. Godfrey were supported by the NIH and research fellowships (M.J. Smyth and D.I. Godfrey) from the NHMRC.

Received for publication April 4, 2005, and accepted in revised form August 9, 2005.

Address correspondence to: Geoffrey Hill, Bone Marrow Transplantation Laboratory, Queensland Institute of Medical Research, 300 Herston Road, Brisbane, Queensland 4006, Australia. Phone: 61-73845-3773; Fax: 61-7-3845-3509; E-mail: geoff.hill@qimr.edu.au.
1. Godfrey, D.I., MacDonald, H.R., Kronenberg, M., Smyth, M.J., and Van Kaer, L. 2004. NKT cells: what's in a name? Nat. Rev. Immunol. 4:231-237.

2. Godfrey, D.I., Hammond, K.J., Poulton, L.D., Smyth, M.J., and Baxter, A.G. 2000. NKT cells: facts, functions and fallacies. Immunol. Today. 21:573-583.

3. Gumperz, J.E. 2004. Antigen specificity of semiinvariant CD1d-restricted T cell receptors: the best of both worlds? Immunol. Cell Biol. 82:285-294.

4. Crowe, N.Y., et al. 2003. Glycolipid antigen drives rapid expansion and sustained cytokine production by NK T cells. J. Immunol. 171:4020-4027.

5. Higuchi, M., et al. 2002. Immune tolerance to combined organ and bone marrow transplants after fractionated lymphoid irradiation involves regulatory NK T cells and clonal deletion. J. Immunol. 169:5564-5570.

6. Zeng, D., et al. 1999. Bone marrow NK1.1(-) and NK1.1(+) T cells reciprocally regulate acute graft versus host disease. J. Exp. Med. 189:1073-1081.

7. Lan, F., Zeng, D., Higuchi, M., Higgins, J.P., and Strober, S. 2003. Host conditioning with total lymphoid irradiation and antithymocyte globulin prevents graft-versus-host disease: the role of CD1reactive natural killer T cells. Biol. Blood Marrow Transplant. 9:355-363.

8. Seino, K.I., et al. 2001. Requirement for natural killer T (NKT) cells in the induction of allograft tolerance. Proc. Natl. Acad. Sci. U. S. A. 98:2577-2581.

9. Smyth, M.J., et al. 2000. Differential tumor surveillance by natural killer (NK) and NKT cells. J. Exp. Med. 191:661-668.

10. Crowe, N.Y., Smyth, M.J., and Godfrey, D.I. 2002. A critical role for natural killer T cells in immunosurveillance of methylcholanthrene-induced sarcomas. J. Exp. Med. 196:119-127.

11. Gillessen, S., et al. 2003. CD1d-restricted T cells regulate dendritic cell function and antitumor immunity in a granulocyte-macrophage colonystimulating factor-dependent fashion. Proc. Natl. Acad. Sci. U. S. A. 100:8874-8879.

12. Terabe, M., et al. 2003. Transforming growth factor-beta production and myeloid cells are an effector mechanism through which CD1d-restricted $\mathrm{T}$ cells block cytotoxic $\mathrm{T}$ lymphocyte-mediated tumor immunosurveillance: abrogation prevents tumor recurrence. J. Exp. Med. 198:1741-1752.

13. Smyth, M.J., et al. 2002. NKT cells - conductors of tumor immunity? Curr. Opin. Immunol. 14:165-171.

14. Cashen, A.F., Link, D., Devine, S., and Dipersio, J. 2004. Cytokines and stem cell mobilization for autologous and allogeneic transplantation. Curr. Hematol. Rep. 3:406-412.

15. Pan, L., et al. 1999. Granulocyte colony-stimulating factor-mobilized allogeneic stem cell transplantation maintains graft-versus-leukemia effects through a perforin-dependent pathway while preventing graft- versus-host disease. Blood. 93:4071-4078.

16. Krijanovski, O.I., et al. 1999. Keratinocyte growth factor (KGF) separates graft-versus-leukemia effects from graft-versus-host disease. Blood. 94:825-831.

17. Teshima, T., et al 1999. Interleukin-11 separates graft-versus-leukemia effects from graft-versushost disease after bone marrow transplantation. J. Clin. Invest. 104:317-325.

18. Hill, G.R., et al. 1999. Differential roles of IL-1 and TNFa on graft-versus-host disease and graft versus leukemia. J. Clin. Invest. 104:459-467.

19. Reddy, P., et al. 2003. Pretreatment of donors with interleukin-18 attenuates acute graft-versus-host disease via STAT6 and preserves graft-versus-leukemia effects. Blood. 101:2877-2885.

20. Sykes, M., Abraham, V.S., Harty, M.W., and Pearson, D.A. 1993. IL-2 reduces graft-versus-host disease and preserves a graft-versus-leukemia effect by selectively inhibiting CD4+ T cell activity. J. Immunol. 150:197-205.

21. Yang, Y., et al. 1997. Interleukin-12 preserves the graft-versus-leukemia effect of allogeneic CD8 T cells while inhibiting CD4-dependent graft-versushost disease in mice. Blood. 90:4651-4660.

22. Yang, Y.G., Qi, J., Wang, M.G., and Sykes, M. 2002. Donor-derived interferon gamma separates graft-versus-leukemia effects and graft-versushost disease induced by donor CD8 T cells. Blood. 99:4207-4215

23. Morris, E.S., et al. 2004. Donor treatment with pegylated G-CSF augments the generation of IL-10 producing regulatory $T$ cells and promotes transplant tolerance. Blood. 103:3573-3581.

24. Horowitz, M.M., et al. 1990. Graft-verus-leukemia reactions after bone marrow transplantation. Blood. 75:555-562.

25. Jones, S.C., Murphy, G.F., and Korngold, R. 2003. Post-hematopoietic cell transplantation control of graft-versus-host disease by donor CD425 T cells to allow an effective graft-versus-leukemia response. Biol. Blood Marrow Transplant. 9:243-256.

26. Edinger, M., et al. 2003. CD4+CD25+ regulatory $\mathrm{T}$ cells preserve graft-versus-tumor activity while inhibiting graft-versus-host disease after bone marrow transplantation. Nat. Med. 9:1144-1150.

27. Streeter, P.R., et al. 2001. Progenipoietins: biological characterization of a family of dual agonists of fetal liver tyrosine kinase- 3 and the granulocyte colony- stimulating factor receptor. Exp. Hematol. 29:41-50.

28. Fleming, W.H., Mulcahy, J.M., McKearn, J.P., and Streeter, P.R. 2001. Progenipoietin-1: a multifunctional agonist of the granulocyte colony- stimulating factor receptor and fetal liver tyrosine kinase- 3 is a potent mobilizer of hematopoietic stem cells. Exp. Hematol. 29:943-951.

29. Pullarkat, V., et al. 2003. A phase I trial of SD-9427 (progenipoietin) with a multipeptide vaccine for resected metastatic melanoma. Clin. Cancer Res. 9:1301-1312.

30. MacDonald, K.P., et al. 2003. Donor pretreatment with progenipoietin-1 is superior to granulocyte colony-stimulating factor in preventing graft-versus-host disease after allogeneic stem cell transplantation. Blood. 101:2033-2042.

31. Baker, J., Verneris, M.R., Ito, M., Shizuru, J.A., and Negrin, R.S. 2001. Expansion of cytolytic CD8(+) natural killer $\mathrm{T}$ cells with limited capacity for graftversus-host disease induction due to interferon gamma production. Blood. 97:2923-2931.

32. Kawamura, H., et al. 1999. Expansion of extrathymic $T$ cells as well as granulocytes in the liver and other organs of granulocyte-colony stimulating factor transgenic mice: why they lost the ability of hybrid resistance. J. Immunol. 162:5957-5964.

33. Wilson, S.B., and Delovitch, T.L. 2003. Janus-like role of regulatory iNKT cells in autoimmune disease and tumour immunity. Nat. Rev. Immunol. 3:211-222.

34. Cui, J., et al. 1997. Requirement for Valpha14 NKT cells in IL-12-mediated rejection of tumors. Science. 278:1623-1626.

35. Mapara, M.Y., et al. 2002. Donor lymphocyte infusions mediate superior graft-versus-leukemia effects in mixed compared to fully allogeneic chimeras: a critical role for host antigen-presenting cells. Blood. 100:1903-1909.

36. Nestel, F.P., Price, K.S., Seemayer, T.A., and Lapp, W.S. 1992. Macrophage priming and lipopolysaccharide-triggered release of tumor necrosis factor alpha during graft-versus-host disease. J. Exp. Med. 175:405-413.

37. MacDonald, K.P., et al. 2005. Cytokine expanded myeloid precursors function as regulatory antigenpresenting cells and promote tolerance through IL-10-producing regulatory T cells. J. Immunol. 174:1841-1850.

38. Schmaltz, C., et al. 2002. T cells require TRAIL for optimal graft-versus-tumor activity. Nat. Med. 8:1433-1437.

39. Pan, L., Delmonte, J., Jalonen, C.K., and Ferrara, J.L.M. 1995. Pretreatment of donors with granulocyte colony-stimulating factor polarizes donor T lymphocytes toward type 2 cytokine production and reduces severity of experimental graft versus host disease. Blood. 86:4422-4429.

40. Vigorito, A.C., et al. 1998. A randomised, prospective comparison of allogeneic bone marrow and peripheral blood progenitor cell transplantation in the treatment of haematological malignancies. Bone Marrow Transplant. 22:1145-1151.

41. Schmitz, N., et al. 1998. Allogeneic bone marrow transplantation vs filgrastim-mobilised peripheral blood progenitor cell transplantation in patients with early leukaemia: first results of a randomised multicentre trial of the European Group for Blood 
and Marrow Transplantation. Bone Marrow Transplant. 21:995-1003.

42. Blaise, D., et al. 2000. Randomized trial of bone marrow versus lenograstim-primed blood cell allogeneic transplantation in patients with early-stage leukemia: a report from the Societe Francaise de Greffe de Moelle. J. Clin. Oncol. 18:537-546.

43. Powles, R., et al. 2000. Allogeneic blood and bonemarrow stem-cell transplantation in haematological malignant diseases: a randomised trial. Lancet. 355:1231-1237.

44. Bensinger, W.I., et al. 2001. Transplantation of bone marrow as compared with peripheral-blood cells from HLA-identical relatives in patients with hematologic cancers. N. Engl. J. Med. 344:175-181.

45. Oehler, V.G., et al. 2005. Randomized trial of allogeneic related bone marrow transplantation versus peripheral blood stem cell transplantation for chronic myeloid leukemia. Biol. Blood Marrow Transplant. 11:85-92.

46. Rutella, S., et al. 2002. Role for granulocyte colonystimulating factor in the generation of human $\mathrm{T}$ regulatory type 1 cells. Blood. 100:2562-2571.

47. Egi, H., Hayamizu, K., Ohmori, I., Kitayama, T., and Asahara, T. 2002. Upregulation of intragraft interleukin- 10 by infusion of granulocyte colony-stimulating factor-mobilized donor leukocytes. Transpl. Int. 15:479-485.

48. Husmann, L.A., and Bevan, M.J. 1988. Cooperation between helper T cells and cytotoxic T lymphocyte precursors. Ann. N. Y. Acad. Sci. 532:158-169.

49. Smyth, M.J., et al. 2002. Sequential production of interferon-gamma by NK1.1 $(+)$ T cells and natural killer cells is essential for the antimetastatic effect of alpha-galactosylceramide. Blood. 99:1259-1266.

50. Stewart, T.J., Smyth, M.J., Fernando, G.J., Frazer, I.H., and Leggatt, G.R. 2003. Inhibition of early tumor growth requires J alpha 18-positive (natural killer T) cells. Cancer Res. 63:3058-3060.

51. Fujii, S., Shimizu, K., Smith, C., Bonifaz, L., and Steinman, R.M. 2003. Activation of natural killer $\mathrm{T}$ cells by alpha-galactosylceramide rapidly induces the full maturation of dendritic cells in vivo and thereby acts as an adjuvant for combined CD4 and CD8 T cell immunity to a coadministered protein. J. Exp. Med. 198:267-279.

52. Denkers, E.Y., Scharton-Kersten, T., Barbieri, S., Caspar, P., and Sher, A. 1996. A role for CD4+ NK1.1+ T lymphocytes as major histocompatibility complex class II independent helper cells in the generation of CD8+ effector function against intracellular infection. J. Exp. Med. 184:131-139.

53. Johnson, T.R., Hong, S., Van Kaer, L., Koezuka, Y., and Graham, B.S. 2002. NK T cells contribute to expansion of CD8 $(+) \mathrm{T}$ cells and amplification of antiviral immune responses to respiratory syncytial virus. J. Virol. 76:4294-4303.

54. Stober, D., Jomantaite, I., Schirmbeck, R., and Rei- mann, J. 2003. NKT cells provide help for dendritic cell-dependent priming of MHC class I-restricted CD8+ T cells in vivo. J. Immunol. 170:2540-2548.

55. Behar, S.M., Podrebarac, T.A., Roy, C.J., Wang, C.R., and Brenner, M.B. 1999. Diverse TCRs recognize murine CD1. J. Immunol. 162:161-167.

56. Morecki, S., et al. 2004. Effect of KRN7000 on induced graft-vs.-host disease. Exp. Hematol. 32:630-637.

57. Hashimoto, D., et al. 2005. Stimulation of host NKT cells by synthetic glycolipid regulates acute graft-versus-host disease by inducing Th2 polarization of donor T cells. J. Immunol. 174:551-556.

58. Shlomchik, W.D., et al. 1999. Prevention of graft versus host disease by inactivation of host antigenpresenting cells. Science. 285:412-415.

59. Matte, C.C., et al. 2004. Donor APCs are required for maximal GVHD but not for GVL. Nat. Med. 10:987-992.

60. Honda, S., et al. 1997. Expansion of an unusual population of Gr-1+CD3int cells in the lymph nodes and other peripheral organs of mice carrying the lpr gene. Cell Immunol. 177:144-153.

61. Yanagisawa, K., et al. 2002. Impaired proliferative response of $\mathrm{V}$ alpha $24 \mathrm{NKT}$ cells from cancer patients against alpha-galactosylceramide. J. Immunol. 168:6494-6499.

62. Tanaka, J., et al. 2004. Cytolytic activity and regulatory functions of inhibitory NK cell receptorexpressing $\mathrm{T}$ cells expanded from granulocyte colony-stimulating factor-mobilized peripheral blood mononuclear cells. Blood. 104:768-774.

63. Crough, T., Nieda, M., and Nicol, A.J. 2004. Granulocyte colony-stimulating factor modulates $\alpha$-galactosylceramide-responsive human $\mathrm{V} \alpha 24^{+} \mathrm{V} \beta 11^{+} \mathrm{NKT}$ cells. J. Immunol. 173:4960-4966.

64. Haraguchi, K., et al. 2004. Recovery of Valpha24(+) NKT cells after hematopoietic stem cell transplantation. Bone Marrow Transplant. 34:595-602.

65. Leite-De-Moraes, M.C., et al. 1998. IL-4-producing NK T cells are biased towards IFN-gamma production by IL-12. Influence of the microenvironment on the functional capacities of NK T cells. Eur. J. Immunol. 28:1507-1515.

66. Leite-De-Moraes, M.C., et al. 2001. IL-18 enhances IL-4 production by ligand-activated NKT lymphocytes: a pro-Th2 effect of IL-18 exerted through NKT cells. J. Immunol. 166:945-951.

67. Leite-De-Moraes, M.C., et al. 1999. A distinct IL-18induced pathway to fully activate NK T lymphocytes independently from TCR engagement. J. Immunol. 163:5871-5876.

68. Taylor, P.A., Lees, C.J., and Blazar, B.R. 2002 The infusion of ex vivo activated and expanded CD4(+)CD25(+) immune regulatory cells inhibits graft-versus-host disease lethality. Blood. 99:3493-3499.

69. Hoffmann, P., Ermann, J., Edinger, M., Fath- man, C.G., and Strober, S. 2002. Donor-type $\mathrm{CD} 4(+) \mathrm{CD} 25(+)$ regulatory $\mathrm{T}$ cells suppress lethal acute graft-versus-host disease after allogeneic bone marrow transplantation. J. Exp. Med. 196:389-399.

70. Cohen, J.L., Trenado, A., Vasey, D., Klatzmann, D., and Salomon, B.L. 2002. CD4(+)CD25(+) immunoregulatory T cells: new therapeutics for graft-versus-host disease. J. Exp. Med. 196:401-406.

71. Cretney, E., et al. 2002. Increased susceptibility to tumor initiation and metastasis in TNF-related apoptosis-inducing ligand-deficient mice. J. Immunol. 168:1356-1361.

72. Yu, K.O., et al. 2005. Modulation of CD1d-restricted NKT cell responses by using $\mathrm{N}$-acyl variants of alphagalactosylceramides. Proc. Natl. Acad. Sci. U. S. A. 102:3383-3388.

73. Hill, G.R., et al. 1997. Total body irradiation and acute graft versus host disease. The role of gastrointestinal damage and inflammatory cytokines. Blood. 90:3204-3213.

74. Hill, G.R., et al. 1998. Interleukin-11 promotes T cell polarization and prevents acute graft-versushost disease after allogeneic bone marrow transplantation. J. Clin. Invest. 102:115-123.

75. Cooke, K.R., et al. 2000. Tumor necrosis factoralpha neutralization reduces lung injury after experimental allogeneic bone marrow transplantation. Transplantation. 70:272-279.

76. Contag, P.R., Olomu, I.N., Stevenson, D.K., and Contag, C.H. 1998. Bioluminescent indicators in living mammals. Nat. Med. 4:245-247.

77. Reddy, P., et al. 2001. Interleukin-18 regulates acute graft-versus-host disease by enhancing Fas-mediated donor T cell apoptosis. J. Exp. Med. 194:1433-1440.

78. Schmaltz, C., et al. 2001. Differential use of Fas ligand and perforin cytotoxic pathways by donor $\mathrm{T}$ cells in graft-versus-host disease and graft-versusleukemia effect. Blood. 97:2886-2895.

79. Kienzle, N., Olver, S., Buttigieg, K., and Kelso, A. 2002. The fluorolysis assay, a highly sensitive method for measuring the cytolytic activity of $\mathrm{T}$ cells at very low numbers. J. Immunol. Methods. 267:99-108.

80. Vremec, D., Pooley, J., Hochrein, H., Wu, L., and Shortman, K. 2000. CD4 and CD8 expression by dendritic cell subtypes in mouse thymus and spleen. J. Immunol. 164:2978-2986.

81. Lipford, G.B., Bendigs, S., Heeg, K., and Wagner, H. 2000. Poly-guanosine motifs costimulate antigen-reactive CD8 T cells while bacterial CPG-DNA affect $\mathrm{T}$-cell activation via antigen-presenting cellderived cytokines. Immunology. 101:46-52.

82. Matsuda, J.L., et al. 2000. Tracking the response of natural killer $\mathrm{T}$ cells to a glycolipid antigen using CD1d tetramers. J. Exp. Med. 192:741-754.

83. Hammond, K.J., et al. 2001. CD1d-restricted NKT cells: an interstrain comparison. J. Immunol. 167:1164-1173. 